\title{
Knocked Out: The Once and Future Demise of Football
}

\author{
Chris D. Birkel*
}

The National Football League (NFL) is the most popular professional sports league in the United States. Fans spend billions of dollars every year on tickets and paraphernalia. Television networks pay billions of dollars to broadcast games that attract millions of viewers. ${ }^{1}$ Millions of fans play fantasy football and estimated millions illicitly gamble on football outcomes. But for all the success the NFL enjoys there appear to be mounting near-term difficulties.

There has been seemingly no end to the negative publicity the NFL has suffered recently. Player behavior has been half the story; from the very recent events involving Adrian Peterson's "whooping" of his four year old son ${ }^{2}$ to the Ray Rice punch of his female significant other in an elevator, ${ }^{3}$ there has been one bad revelation after another. Worst of all the situations is that of Aaron Hernandez who was once a promising tight end for the New England Patriots but now waits in jail for his trials on multiple counts of homicide. ${ }^{4} \mathrm{NFL}$ management's reaction to these events has been broadly criticized as uneven, insensitive, or inappropriate, leading some observers to question how long NFL Commissioner Roger Goodell can effectively serve league owners' interests. ${ }^{5}$

* Assistant Professor of Business Law, College of Charleston; JD, University of Michigan Law School (2001); MPP, John F. Kennedy School of Government at Harvard University (1997).

1. Frank Pallotta, NFL Conference Championship Games Bring Big Ratings for Fox, CBS, CNN Money, Jan. 19, 2015, http://money.cnn.com/2015/01/19/media/nfl-nfc-afc-championshipratings-for-fox-cbs/.

2. Steve Eder \& Pat Borzi, N.F.L. Rocked Again as Adrian Peterson Faces a Child Abuse Charge, N.Y. TIMES, Sept. 12, 2014, available at http://www.nytimes.com/2014/09/13/sports/football/adrian-peterson-indicted-on-child-injurycharge.html.

3. David Carr, In Ray Rice Scandal, TMZ Scores on a Fumble, N.Y. Times, Sept 14, 2014, available at $\mathrm{http}: / /$ www.nytimes.com/2014/09/15/business/media/in-ray-rice-scandal-tmz-scoreson-a-fumble.html.

4. John R. Ellement, Aaron Hernandez Bought Cousin's Silence, Prosecutors Say, Bos. GLOBE, August 11, 2014, available at http://www.bostonglobe.com/metro/2014/08/11/aaronhernandez-due-back-court-lloyd-case/yK1YvbrjMCPYc2Vpp5ZVjJ/story.html.

5. Nolan Feeney, NFL Commissioner Roger Goodell Facing Mounting Pressure to Resign, TiME, Sept. 14, 2014, available at http://time.com/3373185/roger-goodell-resignation-pressureray-rice/. 
But for all the player misconduct reports that receive ongoing headlines, the most important story involves players alleging significant tort damages from head trauma. ${ }^{6}$ The initial settlement agreement between approximately 4500 former NFL Players, represented by the NFL Players Association (NFLPA), and NFL owners drew significant media attention when an initial settlement agreement was reached between the Players' Union and the NFL. The lawsuit alleged damages for repeated concussions suffered by NFL players, sustained while playing football. ${ }^{8}$ U.S. District Judge Anita Brody, who expressed concerns that a 765 million dollar cap on total payouts might not be enough to cover all potential future claims, did not accept the first settlement agreement. ${ }^{9}$ Once the NFL agreed to lift the total payout cap to 870 million dollars, ${ }^{10}$ Judge Brody preliminarily approved the settlement. ${ }^{11}$ The NFL had also faced separate lawsuits by the families of some deceased former players. ${ }^{12}$ Most of those cases were consolidated and became part of the settlement agreement, ${ }^{13}$ but some individual lawsuits remain. ${ }^{14}$

One such lawsuit revolves around the suicide death Junior Seau, voted into the NFL Hall of Fame posthumously, ${ }^{15}$ who had numerous head traumas. ${ }^{16}$ Seau's family has decided to pursue a separate lawsuit against the NFL. ${ }^{17}$ The

6. In re National Football Players' Concussion Injury Litigation, No. 2:12-md-02323-AB
(D. $\quad \mathrm{Pa} \quad$ filed $\quad$ June http://www.abc.net.au/radionational/linkableblob/5546098/data/nfl-master-complaint-data.pdf' .

7. See, e.g., Chris Burke, Players, Agents React to NFL's \$765M Concussion Lawsuit Settlement, SPORTS ILluSTRATED, Aug. 29, 2013, available at http://nfl.si.com/2013/08/29/nflconcussion-lawsuit-settlement-player-reaction/ (discussing player responses to the initial settlement agreement that was eventually rejected by the District Court). This paper lays out the reasoning behind the claim that the cited lawsuit will prove most important.

8. See Jeremy P. Grove, Three and Out: The NFL's Concussion Liability and How Players Can Tackle the Problem, 14 VAND. J. ENT. \& TECH. L. 649 (2012) for a treatment of the issues of concussions and the medical community's awareness of the dangers associated with repeated concussions.

9. Associated Press, Federal Judge Approves NFL Concussion Settlement, NFL.com, Jul. 7, 2014, http://www.nfl.com/news/story/0ap2000000363672/article/federal-judge-approves-nflconcussion-settlement.

10. Id.

11. Id.

12. Nathan Fenno, Hall of Famer Mike Webster's Estate, Others Sue NFL Over Concussions, L.A. TIMES, Mar. 21, 2014, available at http://articles.latimes.com/2014/mar/21/sports/la-sp-sn-mike-webster-nfl-concussions-lawsuit20140321 (discussing the case between the estate of NFL Hall of Famer Mike Webster and dozens of former players suing the league over concussion injuries that may be merged with the class action suit, as discussed supra note 1).

13. Mike Florio, Concussion Settlement Notices Show Up on NFL.com, NBC SPORTS, Aug. 11, 2014, http://profootballtalk.nbcsports.com/2014/08/11/concussion-settlement-noticesshow-up-on-nfl-com/.

14. Fenno, supra at note 12.

15. Jeff Legwold, Junior Seau Headlines HOF Class, ABC News, Jan.15, 2015, available at http://abcnews.go.com/Sports/junior-seau-headlines-hof-class/story?id=28634268.

16. Associated Press, Junior Seau's Family Sues NFL, ESPN, Jan. 24, 2013, available at http://espn.go.com/nfl/story/_id/8872778/junior-seau-family-files-wrongful-death-suit-vs-nfl.

17. Mark Fainaru-Wada \& Steve Fainaru, Seau's Opt Out of NFL Concussion Deal, ABC 
Seau family believes the self-inflicted gunshot death of the former NFL player was a result of the brain damage suffered during Seau's football career. ${ }^{18}$ If a sizable judgment is rendered for the family, one imagines the issue of concussions and brain damage will once again dominate football related press. ${ }^{19}$

These cases allege that the NFL, as an employer, had a duty to reasonably protect the health of its employees from known risks. ${ }^{20}$ Further, it was alleged the NFL owed a duty to disclose to its employee-players non-obvious, known risks. The players alleged that the NFL breached its duty by not adequately informing the Players and the Players' Association of the dangers that concussions and head trauma might pose. ${ }^{21}$ One of the reasons the NFL Players' class action lawsuit survived summary judgment in pre-trial motions on the way to a trial and potential jury verdict was the allegation that the NFL had evidence of the long-term effects of concussions and that therefore all the damages were foreseeable by the NFL. ${ }^{22}$ Without properly informing the players of the dangers their job might hold the NFL might be liable for resulting damages. ${ }^{23}$

Media headlines focus on the huge number of 870 million dollars, including 112 million dollars allotted for attorney's fees. ${ }^{24}$ Although a lot of money, professional football generates average annual franchise revenue of almost 300 million dollars for its 32 teams and can therefore sustain that sort of expense as long as it is a one-off occurrence. ${ }^{25}$ Further, because the NFL is a 501(c)(6) not-for-profit organization, there have been calls to remove the League's tax-exempt status in light of allegations of bad behavior ${ }^{26}$ and what some see as undeserved favorable tax treatment. ${ }^{27}$ Lawsuits and changes to the

News, Sept. 3, 2014, available at http://abcnews.go.com/Sports/seaus-opt-nfl-concussiondeal $/$ story? id $=25224896$.

18. Id.

19. See, e.g., Daniel Gandert \& Esther Kim, The NFL's Headache: Issues with California Workers' Compensation for Continuous Head Traumas in Former Professional Football Players, 45 U. OF TOLEDO L. R. 57 (2013) for a discussion of one aspect of the law that will affect the Seau family's lawsuit. Seau played in California for the San Diego Chargers and also ended his own life in California.

20. National Football Players' Concussion Injury Litigation, supra note 6, at 20-25, 35-46.

21. Id. at 36. The players' lawsuit alleges conspiratorial behavior to subvert scientific understanding of brain traumas associated with concussions in Paragraph 151 of the complaint.

22. Id. at 53 .

23. Id. at 85 .

24. Associated Press, supra note 9.

25. Brent Schrotenboer, NFL Takes Aim at \$25 Billion, but at What Price?, USA TODAY, Feb. 5, 2014, available at http://www.usatoday.com/story/sports/nfl/super/2014/01/30/superbowl-nfl-revenue-denver-broncos-seattle-seahawks/5061197/ ("The National Football League hopes to achieve $\$ 25$ billion in annual revenue by 2027 , up from about $\$ 10$ billion now.”).

26. See National Football Players' Concussion Injury Litigation, supra note 6, at 58-62.

27. Kristi Dosh, Examining NFL's Tax-Exempt Status, ESPN, Jun. 6, 2013, available at http://espn.go.com/nfl/story/_id/9342479/examining-nfl-tax-exempt-status-challenged-ussenator-tom-coburn; see also Andrew B. Delaney, Taking a Sack: The NFL and its Undeserved Tax-Exempt Status, May 11, 2010, available at http://ssrn.com/abstract=1605281. 
tax treatment of the league, taken together, represent a strategic threat to the NFL's financial stability. While the NFL possesses the financial wherewithal and legal representation to have delayed for many years a final judgment, the NFL may have been motivated to settle to avoid unwanted media and political scrutiny. ${ }^{28}$ Further, NFL owners were reportedly willing to settle the instant class action lawsuit rather than face the risk of a potentially larger judgment of damages a jury might deliver. ${ }^{29}$

The NFL likely intended to limit potential future lawsuits by settling the class action case. ${ }^{30}$ However, the best way to foreclose any future lawsuits is for the NFL and the NFLPA to negotiate language in a future union contract. ${ }^{31}$ One aspect of the proposed settlement agreement includes as much as $\$ 10$ million for medical research and education of players and team employees. ${ }^{32}$ By educating and informing NFL players about the possible dangers of playing football, the NFL may be able to make affirmative defenses in potential future lawsuits - such as assumption of risk - even without a collective bargaining agreement with the union. Because the most highly capitalized American sports organization was willing to settle for such a large sum, this paper anticipates the likely viability of lawsuits against other American football organizations, in coming years.

\section{A. FoOtBALL BEYOND THE NFL}

The NFL depends on the National Collegiate Athletic Association (NCAA) to supply well-trained employees to the professional ranks. Any disruption in the supply of those highly skilled football players would likely adversely affect the NFL's high quality on-field product. As grown men, college football players suffer concussions by similar mechanisms as their professional football counterparts. ${ }^{33}$ Therefore it should come as little surprise

28. Howard Bloom, What Happens Next in NFL Concussion Lawsuit Settlement, SPORTS BUS. NEwS, Aug. 29, 2013, available at http://www.sportsbusinessnews.com/content/whathappens-next-nfl-concussion-lawsuit-settlement (discussing the first settlement attempt) ("By settling, the NFL also gains considerable benefits. The league avoids further litigation of a lawsuit that has threatened billions of dollars in damages and dramatic effects on team insurance costs. For team owners, they were faced with the possibility of paying some of those damages and also seeing their franchise values potentially drop. While the league was optimistic it would prevail in litigation, there was no guarantee it would. By settling, the league obtains control over the controversy and prevents the prospect of jury of a dozen people from dictating the league's future.").

29. Id.

30. Id.

31. Id. ("A settlement would not bar future lawsuits by other players. In order for the settlement to have such legal effect, the NFLPA and NFL would need to collectively-bargain an agreement that the settlement has such an effect. This agreement would be amended to the collective bargaining agreement and would be incorporated by reference into the CBA. There is no indication yet whether the NFL and NFLPA will reach such an agreement, but expect it to happen at some point.").

32. Associated Press, supra note 9.

33. See Delaney J. Scott, Al-Kashmiri Ammar \& Correa Jose, Mechanisms of Injury for 
that the NCAA also faced a class action lawsuit from former football players who were concussed or suffered head injuries. ${ }^{34}$

The NCAA settled part of its concussion-related lawsuit in July of $2014 .^{35}$ "The settlement ... include[d] $\$ 70$ million for screening for athletes who suspect brain injuries, and $\$ 5$ million for research." 36 This action may help prevent lawsuits arising from future injuries against the NCAA. However individual personal injury lawsuits against the NCAA and member schools that happened prior to the July 2014 settlement may proceed. ${ }^{37}$ One expects plaintiffs' attorneys to view these settlements as evidence that they can win on behalf of injured players against member schools, if not the NCAA itself. ${ }^{38}$

\section{B. Youth FoOTBALL LAWSUITS}

College football depends on a myriad of youth football organizations to provide skilled and experienced players. Primary amongst those groups are the thousands of local school systems that fund high school and middle school football conferences. Even further down the supply chain for the labor that will someday compete on televised games, there are thousands of Pee Wee, Pop Warner and other little league programs that supply the middle and high schools with their football talent. ${ }^{39}$ Similarly to participation at the collegiate level, disruption in youth participation - for any reason - is likely to negatively impact the game of football.

It is not clear how the medical science-still a matter of contention ${ }^{40}-$ behind the NFL players' lawsuit will affect the thousands of Pee Wee, middle school, high school and even college teams that face a "growing body of

Concussions in University Football, Ice Hockey and Soccer, 24 ClinICAL J. OF SPORT MED. 233, 233 (2014) (stating that "the mechanisms of injury for concussions in football are similar to previously published research on professional football players").

34. Sara Ganim, NCAA Reaches Head Injury Settlement, CNN.COM, Jul. 29, 2014, available at $\mathrm{http} / /$ www.cnn.com/2014/07/29/us/ncaa-settlement-head-injuries/.

35. Id.

36. Id.

37. Id.

38. As a defendant, the NCAA may hope to stave off future lawsuits by settling the abovementioned lawsuit. However, enterprising plaintiffs' attorneys are likely to take a different view, especially with regard to individual university defendants. The distinction between the NFL 'and university athletics is the NFL's ability to negotiate with the NFLPA as the sole representative of the players' interests. University athletics has no such union, making it unlikely all universities will be able to avoid lawsuits, even if the NCAA is able to do so.

39. See Steve Fainaru \& Mark Fainaru-Wata, Youth Football Participation Drops, ESPN.COM, Nov. 14, 2013, http://espn.go.com/espn/otl/story/_page/popwarner/pop-warneryouth-football-participation-drops-nfl-concussion-crisis-seen-causal-factor ("USA Football, a national governing body partially funded by the NFL, said participation among players ages 6 to 14 fell from 3 million to 2.8 million in 2011, a 6.7 percent decline.”).

40. The question of whether adult football players who suffer concussions should continue to play is not significantly in dispute. See Gove, supra note 8 , for a discussion on the question about the rate of injury to youth football participants; see also Ray W. Daniel, Steven Rowson \& Stefan M. Duma, Head Impact Exposure in Youth Football: Middle School Ages 12-14 Years 136 J. BIOMECHANICAL ENGINEERING 1 (2014) (discussing the limited empirical data available). 
evidence"41 that concussion and brain trauma injuries have long-lasting health effects. $^{42}$ The myriad local organizations could face expensive legal fees if plaintiffs emerge. ${ }^{43}$ But it is not just the threat of lawsuits that should concern football enthusiasts. ESPN reports that Pee Wee football participation has dropped $9.5 \%$ over the last two years ${ }^{44}$, which happens to coincide with press coverage of the NFLPA concussion lawsuit.

While many of the football organizations could be poor targets for lawsuits due to a lack of funds to pay judgments, they may continue to lose participants over health concerns. ${ }^{45}$ Further, every lawsuit filed that receives attention, whether national or local, will likely fuel parent concerns about the safety of the sport, leading some parents to find other activities for their children. ${ }^{46}$ If parents withdraw younger participants from football, the number of experienced, talented players from which high schools and colleges field teams will necessarily also decrease. This could lead to diminished competition and perhaps even fewer high school and intercollegiate teams.

The scientific proof of causation and injury might not be as robust for youngsters as it is alleged to be for adults playing football. ${ }^{47}$ The force necessary to sustain concussions and other brain trauma can be clearly demonstrated at the professional and university levels, ${ }^{48}$ where at the youth level the force of impacts are generally greatly diminished. However, the evidence may instead indicate few differences between the effects of adult and youth participants. ${ }^{49}$ Consequently, not only medical researchers but also

41. The phrase "a growing body of evidence" appears in more than 6500 articles alongside the words "football" and "concussion" indicating both overuse of a stock phrase and a trend in reporting about football injuries.

42. Melissa Healy, Head Injuries in One Football Season Cause Measurable Brain Damage, L.A. TIMES, Dec. 11, 2013, http://www.latimes.com/science/sciencenow/la-sci-sn-braininjuries-in-sports-without-concussions-20131211-story.html (citing a study by Dr. Thomas McAllister of Indiana University: “The new results don't resolve the matter, but they do suggest that repetitive blows to the head are not without consequence, even when an athlete is able to get up and keep playing.").

43. Liz Neporent, Experts: New Sports Concussion Rules a Game Changer, ABC News, Mar. 19, 2013, http://abcnews.go.com/Health/sports-concussion-rules-game-changerexperts/story?id=18757866 (stating "[a]thletes high school age and younger will now be treated more conservatively than collegiate athletes and pros because, Alessi pointed out, a growing body of evidence shows they take longer to recover from concussion.").

44. Fainaru \& Fainaru-Wata, supra note 39.

45. Id.

46. Id. Granted, this is informed speculation but it does conform to the evidence of parent behavior, both in the stories cited above and in anecdotal observations of parent behavior.

47. Neporent, supra note 43 (writing that "'[e]ven then the coaching staff didn't recommend a trip to the doctor, but she finally told us what was going on, so we took her to a pediatrician,' Balzano said. 'After two weeks of headaches, nausea and sensitivity to light, she saw a specialist who diagnosed a concussion. He ordered her to stay out of games and practice for a couple of months."').

48. See generally Daniel, et al., supra note 40.

49. See Baillargeon, et al., Neuropsychological and Neurophysiological Assessment of Sport Concussion in Children, Adolescents and Adults, 26 BRAIN INJ. 211 (2012) (suggesting the negative results associated with concussions across age ranges may be similar). 
attorneys are likely to turn their attentions to high school players' injuries in short order. In anticipation of those inquiries one should expect risk-averse actors, especially insurance companies, to closely monitor the potential liabilities that scientific findings might continue to reveal. ${ }^{50}$ Consequently, universities, school boards, and Pee Wee organizations may face significant upward price pressures to maintain appropriate insurance levels. ${ }^{51}$ Those price pressures may induce some organizations to significantly change their operations, or withdraw from the marketplace entirely.

If that chain of events occurs, one should naturally wonder about the fate of America's most popular sport. However, as all of these events are related to possible future outcomes, this argument must proceed by analogy. Selecting appropriate analogues is the key to such an inquiry and should yield insight into the future pressures football may face.

\section{CRITERIA For ANALOgUeS}

The most appropriate criteria for our argument by analogy must be outlined. The first such criterion is that the activity must have been formerly very popular, especially with young people. The second criterion is that the activity caused either significant injuries or the likelihood of significant injury that led to the threat or reality of significantly higher insurance premiums attendant to prospective lawsuits. The third criterion is that local organizations, businesses or local governments with risk exposure responded to those likely increased insurance premiums by either changing behaviors or otherwise insulating themselves from the threat of cost increases. With those criteria in mind, we turn our analysis to the following products or activities:

1. diving boards; and

2. playground equipment (such as merry-go-rounds, seesaws and monkey bars).

\section{Diving Boards}

There is no consensus regarding the reasons for the widespread disappearance of diving boards from publicly accessible pools. ${ }^{52}$ It is notable

50. See, e.g., James M. Noble \& Dale C. Hesdorffer, Sport-Related Concussions: A Review of Epidemiology, Challenges in Diagnosis, and Potential Risk Factors 23 Neuropsychology Rev. 273 (2013) ("Despite the apparent high incidence of SRC, risk factors determining initial concussion, recovery periods, recurrence, and long-term outcomes remain poorly understood and warrant further study exploring the influence of age, sex, genetics, and athletic factors.").

51. Insurance Forms, POPWARNER, available http://www.popwarner.com/forms/insurance.htm (noting that concussion insurance is capped at four million dollars per league and per association); see also Jon Butler, Team Insurance Program, POPWARNER, May 30, 2014, available at http://www.popwarner.com/Assets/01assets/admin/2014Forms/Insurance+Cover+Memo-May\$2c+2014.pdf (reporting that many insurance companies are expressly excluding concussion coverage while prices have increased).

52. See, e.g., Carl T. Bogus, Fear-Mongering Torts and the Exaggerated Death of Diving 28 HARV. J.L. \& PUB. POL'Y 17, 19 (2004) (arguing that "(1)itigation resulting from injuries 
that the number of pools in the United States increased from roughly 10,800 in the 1950 s to more than $2,300,000$ as of the $2004 .{ }^{53}$ But the number of diving boards continues to shrink even as the number of pools expands. ${ }^{54}$ Therefore, although people can reasonably disagree as to the cause of this development, it is undeniable that something remarkable happened to cause people to change their preferred behavior so dramatically.

One of the schools of thought to explain this change is that people responded to successful lawsuits by removing an unnecessary source of liability. ${ }^{55}$ Under this theory, the few headline-grabbing lawsuits in which plaintiffs were awarded significant judgments led pool owners - whether municipal or private - to avoid not only the potentially enormous loss (despite the marginal chance of the lawsuit), but also, the increased premiums to maintain insurance on the property. ${ }^{56}$ This theory assumes, it would seem, that people across the country evaluated their risk preferences and made rational decisions about how best to avoid the potential negative outcomes of lawsuits. ${ }^{57}$

One might have expected pool owners to take defensive measures, such as informing potential users of the dangers of diving boards and disclaiming any responsibility for negligent torts. These measures might help avoid lawsuits and preserve the activity that so many people enjoy: diving into pools of water. ${ }^{58}$ That so many pool owners did not choose this option suggests some problem with that strategy.

However, the evidence is not at all clear that pool owners could avoid the great expense of a legal defense, even by dispensing with their diving boards. ${ }^{59}$

involving swimming pools and diving boards is not new, not extensive and contrary to Professor Priest's claim - not increasing"); but see Judge Edith H. Jones, Remarks at the Federalist Society Student Symposium (Feb. 20, 2004) (transcript on file with the Harvard Journal of Law \& Public Policy). Yale Law School's Professor Priest claimed that "diving boards have been removed from all public pools ... I talked to their officials and it was because of lawsuits." According to Professor Priest this was because "liability (insurance premiums) increased and companies went out of business."

53. Id. at 20 .

54. Id. at 21 (suggesting that the number of new installations has dropped very little according to industry sources); but see Steve Moore, Off the Deep End: Lawyers Take Our Diving Board, WALL ST. J., Jun. 23, 2006, available at http://online.wsj.com/articles/SB115103297562588515 (noting the removal of a diving board that had been serious injury-free in over 20 years of operation but was removed for insurance reasons).

55. Moore, supra note 54.

56. See, e.g., George L. Priest, Puzzles on the Tort Crisis, 48 OHIO ST. L.J. 497 (1987) (noting the disappearance of diving boards from city schools that have not been replaced).

57. Id. (arguing that withdrawal from certain markets such as the municipal liability and specific coverage exclusions, not just premium increases, have caused the changes in consumer behavior discussed above).

58. Bogus, supra note 52, at 24-30 (arguing that people have continued to jump into water but without the use of diving boards, many of which were installed dangerously by an industry that did not always promote safe pool installation practices).

59. Id. at 22, 31. (arguing that there are no more than a handful published opinions regarding swimming pool injuries despite the nearly 800 spinal cord injuries suffered each year as evidence that litigation expenses should not drive decision making. However, the one case that garnered the most attention was a case from 1991 that resulted in an eleven million dollar 
There are dozens of published lawsuits from appellate courts over the last several decades involving injuries suffered while diving into pools. ${ }^{60}$ Further, there is evidence that pool owners are just as likely to be sued whether they maintain a diving board or not. ${ }^{61}$ In that light, removal (or non-installation) appears to be an ineffective tool for risk management by pool owners. ${ }^{62}$ However, it may be true that insurance companies set higher rates for homeowners with diving boards than those without. ${ }^{63}$ If true that would yield some explanatory value to the decisions of individuals in the marketplace.

If the precise mechanism by which diving boards disappeared is not obvious, what can be observed is that an activity that was previously quite popular largely disappeared as theories of tort liability expanded, insurance companies responded and individuals made independent decisions that seemed to accrue in one direction. ${ }^{64}$ If diving boards are a useful analogue, then one would expect the game of football to face similar pressures.

\section{Playground Equipment}

A similar story is revealed when one examines the history of playground

judgment after a boy was "rendered quadriplegic" in a diving accident. Surely the size of that jury award would make the risk-averse reconsider diving boards on their property even if the risk of suit was very low.).

60. Id. at 19 .

61. See, e.g., Annie Clement \& Kadence A. Otto, Headfirst Aquatic Incident Court Decisions: The Plaintiff's Odds, 17 J. LEgAL ASPECTS OF SPORTS 107, 110-113 (2007) (identifying 247 diving cases that were decided by a Court of appeals that would be found in a Lexis-Nexis database search). Lawsuits have reached the appellate courts for in ground, above ground, pier or dock dives, swings, boats and every other form of water injury this author can imagine.

62. Id.; see also Glenn Anaiscourt, Fine Tuning California's Approach to Injured Participant in Active Sports, 37 LOY. L.A. L. REV. 1273, 1286 (2004) (noting city concerns that a ruling for the plaintiff in Kahn v. East Side Union High School District, 4 Cal. Rptr. 3d 103 (2003) would have opened potential municipal defendants to liability that would have been more than the "entire aquatic poll budget" of an average small city just to cover legal expenses - even if the municipality won).

63. This information is extremely difficult to locate. However, Thomas Spade, Instructor of Accounting at College Charleston Business School, indicated that some of his private practice clients did have contracts with insurance companies that explicitly mentioned the increased rates for diving board installation. Further, Spade claims that diving board repair will result in higher premiums but removal will not lower costs. One such contract was delivered to the author after gaining the client's permission. E-mail from Thomas Spade, Instructor, Coll. of Charleston School of Bus., to author (Oct. 16, 2014) (on file with author).

64. See, e.g., Greg Sobo, Note, Look Before You Leap: Can the Emergence of the Open and Obvious Danger Defense Save Diving from Troubled Waters, 49 Syracuse L. Rev. 175, 176 (1998) Sobo notes the solemn reality that diving, both as a recreational activity and as an amateur sport, is becoming extinct. He cites Marcia Chambers, Whatever Happened to the Sandlot?, NAT'L L.J., 15 (1991). In attributing this change to the fact that tort law has "gotten out of hand," Sobo goes on to quote Chambers' note that "courts across the country have forced 'city pools from Los Angeles to Chicago to New York [to remove] their diving boards."' As Sobo points out, "diving is now prohibited not only from diving boards, but also even from the edge of the pool. In short, tort law has brought the simple act of taking a dive into water, an activity that has been enjoyed since the origin of modern humanity, to the brink of extinction) (internal citations omitted). 
equipment across the United States. ${ }^{65}$ It is easily confirmed by observation that the nature of playgrounds has substantially changed. ${ }^{66}$ Gone are the merry-gorounds of years past. ${ }^{67}$ Monkey bars have largely disappeared too. ${ }^{68}$ Further, seesaws no longer exist in the numbers they once did. ${ }^{69}$ A quick, if anecdotal, look around municipal parks will confirm those facts are true. However, answering the question as to the mechanism that resulted in the disappearance of the playground equipment may be difficult - approaching impossible - to pinpoint.

Whereas homeowners own most swimming pools in the United States, observation indicates the same is not true for playground equipment. ${ }^{70}$ Therefore, one might expect the limitations of liability that public entities enjoy would make them less susceptible to the pressures of potential tort lawsuits. This expectation is not realized, however, judging by the number of appellate cases municipalities and schools face. ${ }^{71}$

While it is true that there have been successful lawsuits against municipalities and schools for injuries incurred on playgrounds, a review of the record indicates a significant number of cases that make it to an appellate court end in judgments for the defendants. ${ }^{72}$ As with diving boards, the potential, threatened cost of defending against lawsuits may be the only inducement necessary to remove (or fail to install) certain types of playground equipment. The increased cost of insurance products may explain this or it may be risk aversion on the part of playground owners.

Again, however, there is no real consensus about the exact mechanism by which so many individual actors have decided to act in parallel. Some argue that insurance premiums have been the main factor, as with diving boards. ${ }^{73}$

65. See, e.g., Robert Heidt, The Avid Sportsman and the Scope for Self-Protection: When Exculpatory Clauses Should Be Enforced, 38 U. RICH. L. REV. 381, 381-382 (2004) (stating that the expansion of tort liability since the 1960 s has coincided with a sharp curtailment of the availability of some recreational activities.n1 For instance, the percentage of hotel, motel, and YMCA swimming pools that offer the use of one and three-meter diving boards has plummeted. . and the percentage of schools and day care centers that offer playground equipment have also declined).

66. Id. at 382 .

67. Id.

68. Id.

69. Id.

70. Healthy Swimming/Recreational Water, Centers for Disease Control and Prevention, http://www.cdc.gov/healthywater/swimming/ (last updated April 8, 2014) (stating that according to the US Centers for Disease Control, there are 306,000 municipal swimming pools in the United States out of nearly eleven million total pools).

71. Clement \& Otto, supra note 62, at 114.

72. See, e.g., Recent Development in the Law: Primary and Secondary Education, 38 J.L. \& EDUC. 154 (page number?) (2009) (finding that from 1997 to 2009 there were 56 appellate cases summarized that involved allegations of liability for injuries incurred during sports or at recess. Of those, four cases were decided for the plaintiffs, five were sent back for trial, and one was decided the defendant was comparably liable for $50 \%$ of the damages to the plaintiff).

73. See, e.g., Hanna Rosin, The Overprotected Kid, The ATlantic, Mar 19, 2014, available at http://www.theatlantic.com/features/archive/2014/03/hey-parents-leave-those-kids- 
Others argue the threat of expensive litigation and risk management by riskaverse public officials is a more likely cause. ${ }^{74}$ What can be observed, however, is the rapid disappearance of certain pieces of playground equipment amidst a relatively few number of successful lawsuits. ${ }^{75}$

Once again, the proposed analogue has explanatory value. Different theories have been forwarded to explain changed consumer behavior but no definitive answer has been forwarded. What remains true is the widespread disappearance of playground equipment that children enjoyed at some risk to safety at precisely the same time insurance premiums began significantly to increase. Therefore, the example of playground equipment may signal the future of American football.

\section{ANALOGY FAILURES}

As with all arguments by analogy, one must acknowledge the weaknesses of the proposed analogues. While it is true that all three activities have been enjoyed by children of similar ages, there are important differences. The most obvious difference is the amount of money football generates. ${ }^{76}$ Football generates significant revenue for many school systems, ${ }^{77}$ many universities, ${ }^{78}$

alone/358631/ (discussing how lawsuits drove behavior: To turn up the pressure, Sweeney and a fellow consultant on playground safety, Joe Frost, began cataloguing the horrors that befell children at playgrounds. Between them, they had testified in almost 200 cases and could detail gruesome specifics - several kids who had gotten their heads trapped or crushed by merry-gorounds; one who was hanged by a jump rope attached to a deck railing; one who was killed by a motorcycle that crashed into an unfenced playground; one who fell while playing football on rocky ground. In a paper they wrote together, Sweeney and Frost called for "immediate inspection" of all equipment that had been installed before 1981, and the removal of anything faulty. They also called for playgrounds nationwide to incorporate rubber flooring in crucial areas) ("In January 1985, the Chicago Park District settled the suit with the Nelsons. Frank Nelson was guaranteed a minimum of $\$ 9.5$ million. Maurice Thominet, the chief engineer for the Park District, told the Chicago Tribune that the city would have to "take a cold, hard look at all of our equipment" and likely remove all the tornado slides and some other structures.... Around the time the Nelson settlement became public, park departments all over the country began removing equipment newly considered dangerous, partly because they could not afford to be sued, especially now that a government handbook could be used by litigants as proof of standards that parks were failing to meet. In anticipation of lawsuits, insurance premiums skyrocketed. As the Tribune reader had intuited, the cultural understanding of acceptable risk began to shift, such that any known risk became nearly synonymous with hazard.").

74. $I d$.

75. Id.

76. Jonathan Zimmerman, Blame Football, not Title IX, L.A. TIMES, Jan. 9, 2014, available at http://articles.latimes.com/2014/jan/09/opinion/la-oe-zimmerman-football-title-ixncaa-20140109. Football revenues also support many non-revenue sports. This could be potentially significant if schools are to remain Title IX compliant and revenues from football deteriorate.

77. Bob Cook, Money, not Competition, is Why States Are Expanding High School Sports

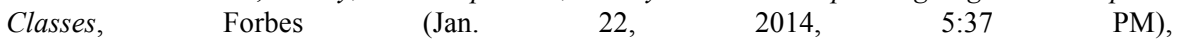
http://www.forbes.com/sites/bobcook/2014/01/22/money-not-competition-is-why-states-areexpanding-high-school-sports-classes/.

78. 2008 College Athletics Revenues and Expenses, ESPN,
http://espn.go.com/ncaa/revenue (last visited Sept. 15, 2014). 
and all NFL franchises. ${ }^{79}$ That could mean greater resistance to the potentially existential threats football faces.

In addition to those with financial interests in the continuation of football, there are other stakeholders who actively support football and are likely to resist obvious threats to America's most popular sport. One of the most prominent of those might be the federal government, which has sponsored the NFL's "Play 60" program to encourage youth fitness. ${ }^{80}$ Additionally, myriad fans support football teams at all levels and would likely resist overt threats to football through legislation.

By contrast, there is a constituency that seems actively hostile to football as an activity. ${ }^{81}$ There have been public officials from New Hampshire ${ }^{82}$ to Texas $^{83}$ to California ${ }^{84}$ and everywhere in between who have suggested the health risks of football cannot be tolerated. In each of those cases, a direct confrontation with football supporters has been difficult. Public sympathy for local government officials who suggest defunding interscholastic football programs has been lacking. Furthermore, there are champions of football in elective office who rally against such moves. Strong political support for football persists both at the local and at the national level. What may surprise the casual observer of both football and history is that modern efforts to limit football are not new.

\section{E. History OF “TEMPERANCE” MOVEMENT AND FOOTBALL}

Nearly 100 years ago, when football was relatively new and helmets were hardly ever worn, there was a move to ban football. ${ }^{85}$ The number of injuries, and especially traumatic brain and neck injuries, led many politically active Americans to call for an end to football. ${ }^{86}$ University teams, without the sort of

79. Darren Rovell, NFL Teams Divided \$6 Billion in Revenue, According to Green Bay Packers Financials, ESPN.COM Jul. 10, 2014, available at http://espn.go.com/nfl/story/_id/11200179/nfl-teams-divided-6-billion-revenue-according-greenbay-packers-financials (reporting that the 32 NFL Franchises split over six billions dollars in revenue in fiscal 2013).

80. See generally NFL Play 60, http://www.nfl.com/play60 (last visited Sept. 15, 2014); see also Office of the First Lady, First Lady's Let's Move! Campaign and NFL's Play 60 Campaign Team up to Tackle Childhood Obesity, WHITE HousE, Sep. 8, 2010, available at http://www.whitehouse.gov/the-press-office/2010/09/08/first-lady-s-let-s-move-campaign-andnfl-s-play-60-campaign-team-tackle-.

81. Daniel J. Flynn, The WAR On Football: SAVING AmericA's Game (2013).

82. Push to Ban Football at New Hampshire High School, My Fox D.C. Oct. 3, 2012, http://www.myfoxdc.com/story/19722262/push-to-ban-football-at-a-new-hampshire-high-school

83. Joseph Baucum, A Walking Contradiction: Texas High Schools, Football and Concussions, October 30, 2013, http://www.austinchronicle.com/daily/sports/2013-10-30/awalking-contradiction-texas-high-schools-football-and-concussions/.

84. David Siders, Jerry Brown signs bill limiting full-contact football practice in California, SACRAMENTO BEE, Jul. 21, 2014, available at http://www.sacbee.com/2014/07/21/6571618/jerry-brown-signs-bill-limiting.html

85. Flynn, supra note 81, at 65 (2013) (internal citations omitted).

86. Id. 
monetary backing they enjoy today, were at risk of disbandment. ${ }^{87}$ Newspapers and opinion leaders of the day called for an end to intercollegiate football contests. $^{88}$

The calls for football's demise grew so intense, in fact, that it took the intervention of a very popular president, Teddy Roosevelt, to save the game as a competitive sport. ${ }^{89}$ Roosevelt publicly supported the college game and his political influence was sufficient to stem the tide of public opinion. ${ }^{90}$ There were football coaches, icons of their day, legends and Hall of Famer football players today who worked with Roosevelt and bent to his will in many respects. ${ }^{91}$ Roosevelt and those coaches negotiated the founding of the National Collegiate Athletic Association (NCAA). ${ }^{92}$ The NCAA promptly set about trying to make the game safer by establishing rules for player safety. ${ }^{93}$

Given this historical context, it is important to understand the objections to football's violence and resulting injuries are persistent and unlikely to disappear. ${ }^{94}$ The perception of violence in football will never be approved in some quasi-political circles, and the concussion lawsuit created an opportunity to express those feelings aloud.

However, the posited threat to football is not from legislation or protests. If the threat is subtle, there will likely be no concerted effort to resist the forthcoming changes. This paper supports the proposition that the most significant long-term threat to competitive football is through the previously cited mechanism: insurance. Whereas the various stakeholders of football would take great care to protect football if the threat were obvious, the disbursed financial threat of higher insurance costs due in part to the threat of litigation may slowly strangle the talent pool, and eventually financial viability, of football at the high school, university, and professional levels.

\section{F. YOUTH FoOTBALL LAWSUITS}

Participation rates for children in Pee-Wee football have dropped considerably since the announcement of the NFLPA's concussion lawsuit. ${ }^{95}$ The decline in participation must mean some drop-off in talent that matriculates to higher levels of the sport.

Each individual league is a self-contained organization. ${ }^{96}$ Most Pee Wee

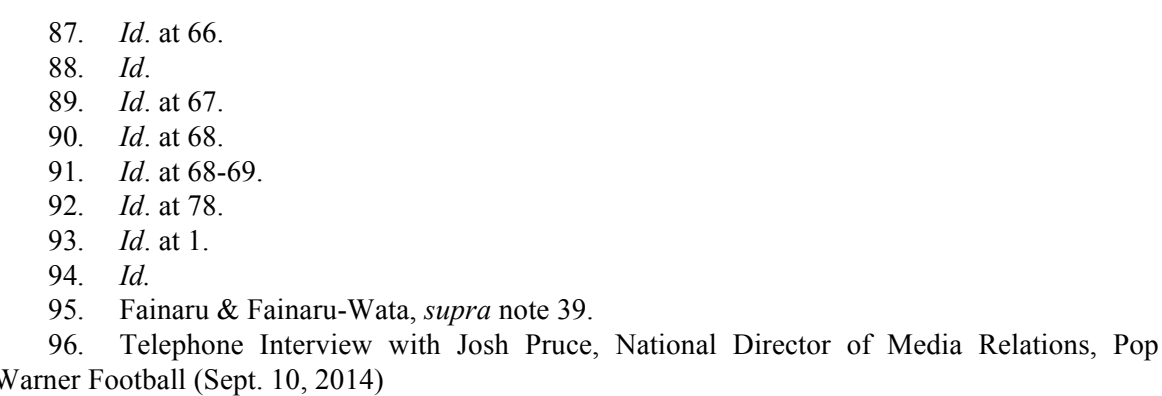


leagues depend on player dues to support their activities. ${ }^{97}$ The organizational structure of Pee Wee leagues may make them less attractive targets for lawsuits because they are typically poorly capitalized, if at all. ${ }^{98}$ However, the leagues do require insurance. ${ }^{99}$ Given the increasing sensitivity of society to the harmful effects of football-related injuries, one can expect the insurance companies to increase prices and to make greater demands of their clients. ${ }^{100}$

One response to the higher insurance costs might be to require emergency medical service at all games. At the margins these cost pressures will lead to increased costs of participation and therefore still lower participation rates. Thus, even as the White House pushes for greater childhood activity through its NFL Play 60 partnership, there can sometimes be factors working at crosspurposes with government policy. ${ }^{101}$ Middle and high school football participation is likely to drop in response to the decreased participation rates of younger players. ${ }^{102}$ Some students will, doubtless, start playing football as teenagers so the effects will not be linear.

The cost pressures that affect school-sponsored football will be different. School systems make somewhat attractive targets for lawsuits, ${ }^{103}$ Although most lawsuits will fail, as they did in the context of municipal playground equipment and swimming pools, the costs of defending lawsuits are significant. ${ }^{104}$ Therefore, insurance costs are leveraged higher. One response to these cost increases is to require students to self-insure if they play football. ${ }^{105}$ This has already started happening and it is a trend that could deter many students, especially those from poorer backgrounds, from football participation in favor of other sports with lower cost structures.

States could respond to these possible difficulties by offering stronger protection to local governments so fewer lawsuits against school systems survive motions to dismiss. Such steps would encourage various stakeholders

97. $\quad I d$.

98. Id. But note, insurance coverage is required for Pop Warner and that many insurance companies have dropped insurance. This indicates that insurance companies anticipate future lawsuits.

99. Id.

100. Id.

101. Carrie Johnson, 20 Years Later, Parts of Major Crime Bill Viewed as Terrible Mistake, NPR (Sept. 12, 2014, 3:32 AM) http://www.npr.org/2014/09/12/347736999/20-yearslater-major-crime-bill-viewed-as-terrible-mistake. Remember too that so-called midnight basketball leagues became a political issue when budgetary considerations overwhelmed the national debate. External forces can thwart even initiatives that have positive health, safety and societal benefits. With the benefit of 20 years' hindsight, canceling midnight basketball may have been a mistake.

102. Fainaru \& Fainaru-Wata, supra note 39.

103. But see Jon Solomon, NCAA and NFHS: High School Football Concussion Case Should End Due to New Mississippi Law, ALA.COM, Apr. 3, 2014, available at http://www.al.com/sports/index.ssf/2014/04/ncaa_and_nfhs_1st_major_high_s.html (explaining that some states have already started to reduce the attractiveness of local school systems as targets of these sorts of lawsuits).

104. Anaiscourt, supra note 62.

105. Id. 
to respond within the political process. Therefore, the outcome of any efforts to give greater statutory protection would be unclear.

\section{G. COLLEGE FoOTBALL}

If participation rates for high school football players drop because of injury concerns and price increases the number of talented players may not support the current number of college programs. Those programs that are financially sound or have great football traditions would still likely attract talented players and maintain high profiles. ${ }^{106}$ However, programs that are financially insecure or that cause significant Title IX problems for their institutions might face increasing pressure to cut football budgets or drop football programs entirely. ${ }^{107}$

These competitive pressures are likely to be coupled with other changes to the legal environment university athletics programs face. With some football players intent on unionizing and collectively bargaining for compensation, college football may face a very different business environment in the near term. ${ }^{108}$ As adults, college football players can theoretically negotiate for waivers of liability claims against the school as a part of their compensation packages. ${ }^{109}$ In fact, some analysts and opinion leaders have argued that colleges abandon the fiction of the amateur athlete and allow players to negotiate a full range of benefits in return for athletic services. ${ }^{110}$

If athletes are allowed to change the cost structure universities face, fewer dollars will be available to non-revenue generating college sports. Athletic departments that maintain profitable football programs may face Title IX difficulties of their own. ${ }^{111}$ If more dollars are committed to football because football players negotiate higher compensation, colleges would be more likely to drop non-revenue producing sports, all things equal.

106. ESPN, supra note 78. It is difficult to imagine a football team like that at the University of Alabama, which produces more than $\$ 120$ million, is likely to experience short-run financial problems. However, a team like Arkansas State that generates little more than $\$ 8$ million may experience significant difficulties.

107. Paula Lavigne, Wrestling with the Truth in Nebraska, ESPN, May 11, 2011, available at $\mathrm{http} / /$ sports.espn.go.com/espn/otl/news/story?id=6488960 (analyzing the financial pressure that resulted in the University of Nebraska-Omaha dropping both men's wrestling and football).

108. Nw. Univ., 198 L.R.R.M. (BNA) 1837 (2014) (NLRB ruling supporting the unionization of Northwestern University football players) available at http://www.chicagotribune.com/sports/chi-nlrb-northwestern-football-union-ruling-20140326htmlstory.html.

109. Id.

110. Steve Eder, A Legal Titan of Sports Labor Disputes Sets His Sights on the N.C.A.A., N.Y. Times, Aug. 27, 2014, http://www.nytimes.com/2014/08/28/sports/jeffrey-kessler-envisionsopen-market-for-ncaa-college-athletes.html.

111. But see Patrick J. McAndrews, Keeping Score: How Universities Can Comply With Title IX Without Eliminating Men's Collegiate Athletic Programs, 1 B.Y.U. EDUC. \& L.J. 111 (2011) (arguing that Title IX Compliance can be accomplished variously). 


\section{H. Positive EXTERNALITIES}

Insurance companies face a defined cost structure based on risk profiles that include potential lawsuits. ${ }^{112}$ The primary benefits they realize are the premium payments from insurance policy holders. ${ }^{113}$ In the context of football, well-capitalized institutions such as the NFL or state land grant colleges and universities would likely be able to bear the full cost of football-related risks. Many football organizations, however, cover only operating expenses on a year-to-year basis by collecting participation fees. ${ }^{114}$ Therefore, many of those local operations are likely to be overburdened by rising insurance premiums. ${ }^{115}$

However, there are quite likely many benefits that accrue to society that are not captured by the insurance companies: classic externalities. For example, football may be an excellent outlet for the aggressions that young men may experience. ${ }^{116}$ The potential for violence in football is criticized in certain quarters. ${ }^{117}$ However football and other rough play may act as a relief valve for many young men who would otherwise turn their aggressions to less productive endeavors. ${ }^{118}$

Another externality not captured by the insurance company business model is the health benefits of competing in a structured sports environment. ${ }^{19}$ Professional football players, for example, outlive their peer age cohort despite the numerous injuries suffered by some participants. ${ }^{120}$ Children who are active are less likely to suffer debilitating diseases such as diabetes or obesity. ${ }^{121}$ Of course, parents have likely been aware of these benefits and that explains why so many of them have been willing to pay for the opportunity to compete on football fields at current prices. The evident risk to football as it currently operates is that insurance costs will deter enough market participants so that the on-field product is seriously degraded and less profitable.

112. See generally Marshall Wilson Reavis III, $\mathrm{PhD}$, Insurance: Concepts and Coverage (2012).

113. Id.

114. Pruce, supra note 96 . There are 1200 Pop Warner associations combined into some smaller number of leagues. Insurance is offered through the Pop Warner organization but can be purchased privately.

115. Patricia H. Born \& W. Kip Viscusi, The Distribution of the Insurance Market Effects of Tort Liability Reforms, HARV. U. (1998), http://www.law.harvard.edu/programs/olin_center/papers/pdf/243.pdf.

116. Flynn, supra note 81 , at 133-45.

117. Andrew O'Hehir, Football, Violence and America's Cultural Divide, Salon (Sept. 13, 2014), http://www.salon.com/2014/09/13/football_violence_and_americas_cultural_divide/ ("If you get your news from mainstream or liberal-leaning sources, and aren't much of a football fan, you might have the impression that the NFL is a crumbling edifice on its way toward obsolescence, plagued by misogyny, homophobia, racial stereotyping and a health crisis encompassing most of its former and present players. There's a thread of truth running through all that, or more than a thread, and one could plausibly argue (as I did, about a year and a half ago) that over the long haul pro football faces insurmountable problems.").

118. Flynn, supra note 81 at 133-45.

119. Id.

120. Id.

121. Id. 


\section{CONCLUSION}

The examples of diving boards and playground equipment above yield a clear picture of the mechanisms by which football might be threatened. Significant changes can happen within one generation, as with diving boards and Merry-go-Rounds that have all but disappeared in America. This threat may seem distant, but as we look back 30 years and see so many things gone from our collective pasts, it should be obvious that football faces significant threats. Lawsuits, successful or not, will drive insurance premiums higher until the perceived future benefits of football participation are outweighed by the price experienced immediately.

There seems to be an increasing call from some quarters to limit participation or cancel football altogether. ${ }^{122}$ Public officials should resist such agitation. The benefits of physical activity are widely known and disbursed throughout society. These benefits are classic externalities. While there are most assuredly dangers associated with running, jumping, and tackling, it is not at all clear that the evidence supports banning, curtailing or dramatically changing tackle football. Whether those changes are driven by legislators who may be resisted politically, or by higher insurance costs that act more subtly, the result would be the same.

Without governmental action to curb the economic incentives - often overblown in popular media - to bring lawsuits against football organizations, the game may be irrevocably harmed. Legislatures may consider limitations on jury awards that might deter lawsuits, for example, although the results of statutory fixes are mixed. ${ }^{123}$ However a more important legislative opportunity is likely the imposition of stringent statutes of limitations that would time bar claims against school systems that date back as far as those faced by the NFL. Legislation of this variety would remove the most important leverage uncertainty - that drives risk premiums and insurance costs.

At the same time there is absolutely a role for government in disseminating appropriate warnings to parents and children where dangers are concerned. Such warnings would allow legal defenses in prospective cases. Legislatures could require explicit warnings for parents and children not only about the physical dangers of sports or the use of playground equipment, but also about assumption of risk. Such legislative measures might remove the economic incentives for pursuing cases against school systems by making it harder to survive motions to dismiss.

122. See, e.g., Jonathan Zimmerman, Football: Unsafe at any Level, L.A. TIMES, Sept. 13, 2014, available at http://www.latimes.com/opinion/op-ed/la-oe-zimmerman-football-dangers20140914-story.html (arguing a la Ralph Nader against the Chevy Corvair, that football is too dangerous). I will note that while the Chevy Corvair is no more, cars are much safer and there are more of them now than ever.

123. Born \& Viscusi, supra note 116. 